\title{
SOME DEVELOPMENTS IN PROTECTION OF THE FOREST FROM INSECTS
}

\author{
By G. L. AINSCOUGH
}

There are proven techniques for the aerial spraying of infestations of defoliators which have been widely used in North America. Costs range from $\$ 1.00$ to $\$ 5.00$ per acre, and, for example in coastal British Columbia, timber stumpage values protected may range from $\$ 100$ to $\$ 1,000$ per acre, or more. Helicopter spraying of water-stored logs as a protection against ambrosia beetles costs 21 to 23 cents per $\mathrm{M} \mathrm{fbm}$ and saves from $\$ 2.00$ to $\$ 8.00$ per $M \mathrm{fbm}$ in degrade losses in sawlogs and peelers.

A further example of the application of simplified economics to insect losses is particularly easy to demonstrate in Coastal British Columbia. I have calculated the allowable cut in the region to be $700 \mathrm{MM}$ c.f. based on current utilization standards. In 1961, the actual cut was 94 per cent of this with only a few sustained yield units being operated below their allowable annual cut.

The killing of a billion feet of merchantable timber, in some public working circle or Tree Farm License would mean either a reduction in the allowable cut or a major salvage program, or both.

When one considers the cost of: disrupting the logging plan, a crash program of camp and road construction, production of species not necessarily suited to current markets, increased fire hazard, and actual volume losses and degrade, a $\$ 200,000$ control project looks like a pretty cheerful alternative.

Obviously, if timber production forestry is to be competitive over the long term, no forest owner could accept the cost of leaving an epidemic uncontrolled any more than he could ignore a fire in his operation on a hot day in July.

The very excellent report of the Intermountain Forest Pest Action Committee, which covers Utah, Nevada, Wyoming and Southern Idaho, identified sixteen high priority control projects for 1962 requiring a total expenditure of over $\$ 3.5$ millions. In 1961 , over $\$ 1.5$ million dollars was spent on control of mountain pine and Engelmann spruce beetles alone. In many of these projects small areas of only a few hundred trees are being treated.

With the exception of "Operation Budworm" in New Brunswick, we in Canada haven't hit this financial league yet. However, in recent years, as insect survey coverage and population assessment techniques have been improved, more insect problems on small areas have been brought to light.

\footnotetext{
${ }^{1}$ Manager of Forestry Division, MacMillan, Bloedel and Powell River Limited, Nanaimo, B.C. Mr. Ainscough is chairman of the Pest Control Committee of the B.C. Loggers Association.
} 
Also, due to the ready availability of a good variety of aircraft and spray equipment dispersed throughout the country it has become feasible to spray smaller infestations, even down to a few hundred acres in more valuable timber.

The continuing development of new insecticides, formulations, techniques of application and equipment is steadily enlarging the opportunity to apply economic control measures by which we can conserve our timber supply.

One of the most significant recent developments in insect protection in British Columbia is the Pest Control Committee of the B.C. Loggers' Association. I believe this committee is unique in North America and that the success with which it has operated merits a brief description of its origin and functions.

In 1955, the Royal Commission on Forestry was advised by the Federal Forest Biology Division of the need for a group of qualified representatives of the timber owners and operators which could act when an insect outbreak occurred. Specifically the brief stated:

"These representatives would be able to interpret developments in insect and disease problems in terms of the policies and operating plans of their parent organizations and to bridge the gap between the processes of securing research and survey data and the process of their application on specific forest properties. Representatives given such assignments should also be capable of assuming organizational and directional responsibilities when large scale control operations are necessary."

The black-headed budworm infestation on Northern Vancouver Island in 1956 involved timber owned by several major companies and the Crown.

The need for cooperative action was obvious and led to the formation of the Pest Control Committee along the lines suggested to the Royal Commission.

The committee is composed of Foresters representing member companies of the B.C. Loggers' Association, and a consulting entomologist who is retained as an advisor, project manager on control projects, and for liaison with various agencies. In addition, the committee invites representatives of the Federal Forestry Department, B.C. Forest Service, Federal Department of Fisheries, Provincial Fish and Game Branch and University of B.C. Department of Zoology to attend meetings and to participate in the planning and execution of control and other projects wherever their interests are affected.

Among the many advantages of such an organization, I would cite three which I consider of greatest value:

1. Ability to act promptly in emergency control operations-to hire aircraft, purchase chemicals and enter into such agreements as it sees fit in order to achieve necessary control.

2. Provide the framework for cooperative action where infestations affect several forest owners.

3. Provide the closest possible liaison with the Forest Biology Laboratory, Department of Fisheries and other Pest Control groups.

I should enlarge on the problem of spraying with insecticides and the coastal salmon fisheries. It is reasonable to say that there could be no spraying to control insects around salmon water-ways had there not been 
the closest cooperation between the Department of Fisheries and the Pest Control Committee.

In the 1957 budworm spray project a cooperative assessment by the Department of Fisheries and the B.C. Game Commission revealed that, in spite of precautions to avoid spraying over major fisheries streams, the damage to salmon fry and other fish and aquatic insects on four important streams was very severe.

The Pest Control Committee has recognized the need for safer control methods and has worked very closely on subsequent projects with the Department of Fisheries and the Forest Biology Laboratory to develop acceptable techniques for aerial spraying against ambrosia beetles attacking water-stored logs and against defoliators.

In the Pest Control Committee's annual program to protect about 70 million fbm of high grade logs from ambrosia beetles, close cooperation with the Department of Fisheries on formulations and timing of the spray have virtually eliminated the chance of fish-kill.

Experimental spraying has been done both here and in New Brunswick to prove the efficiency of dosages of $1 / 4$ and $1 / 2$ pound of DDT per acre instead of the traditional 1 pound which is so lethal to fish. Use of $1 / 4$ pound of DDT per acre was successful in the 1960 black-headed budworm project in the Queen Charlotte Islands and in 1960 and 1961 in New Brunswick.

Bacillus thuringiensis, a spore insecticide which is harmless to fish, was tested with some success in the 1960 project in the Queen Charlottes and in the 1961 project against the green-striped looper at Kitimat.

Another significant development has been the formation of an Inderdepartmental Committee on Forest Spraying. This committee is composed of senior officers of the Federal Departments of Forestry and Fisheries, who meet for the express purpose of reviewing all control projects and encouraging the development of control methods which minimize damage to fish. They have been actively supported by the Pest Control Committee.

Every year, it seems some new and challenging creature emerges from, the woodwork or the woods just to keep us on our toes. Now it is Plinthus carinatus, a snout weevil, which is a native to these parts but only recently has been caught girdling seedlings, particularly, it seems, in plantations. The Federal Insect Laboratory and Pest Control Committee are cooperating in assessing the extent of the damage and the possible use of bait in areas of high population.

Finally, speaking as an industrial forester, I would like to give you my list of developments which I feel must be emphasized if we are to keep timber-production forestry competitive:

1. Adequate insect surveys are required to identify problems before they assume major proportions. In this regard, I am sure that the Department of Forestry is doing an excellent job in British Columbia within the limits of survey staff and travel budgets available. 
2. Continued and expanded testing of experimental control techniques and formulations is needed on small-scale projects. We cannot afford to wait for a major infestation to get experience in control.

3. Expanded research by the Department of Fisheries on toleration of various chemicals and timing of fish movements.

4. An aggressive program is needed to screen and test insecticides which are harmless to mammals and fish.

5. Development of biological control methods, such as the establishment of predators for the control of balsam woolly aphid should be encouraged.

Unfortunately, in the time available I have not been able to go into a lot of interesting things like elimination of Texas screw-worms by irradiation and a rebuttal to Rachel Carson's "Silent Spring". However, I would like to take time before closing to acknowledge the particularly fine work being done by Ray Lejeune and his staff in the Victoria Laboratory and by Hec Richmond who is the key man in our Pest Control Committee. 